\title{
SPONGE UMUM DI TERUMBU-TERUMBU KARANG PERAIRAN TAHUNA KAPULAUAN SANGIHE
}

\author{
Common Sponges of Coral Reefs in Tahuna Sangihe Islands
}

\author{
Walter Balansa $^{1)}$, Aprelia Martina Tomasoa ${ }^{1)}$, Frets Jonas Rieuwpassa ${ }^{2)}$ \\ ${ }^{1}$ Teknologi Budidaya Ikan, Politeknik Negeri Nusa Utara \\ ${ }^{2}$ Teknologi Pengolahan Hasil Laut, Politeknik Negeri Nusa Utara \\ Email: walterbalansa@polnustar.ic.id
}

\begin{abstract}
Abstrak: Sponge makin banyak menarik perhatian para ilmuwan di seluruh dunia bukan karena potensi bioekologisnya saja tetapi juga karena potensi kosmetik dan biomedis dari molekul-molekul bioaktif maupun biomaterial sponge. Sangat disayangkan, pengetahuan tentang diversitas sponge di wilayah dengan biodiversitas tertinggi di dunia seperti Sulawesi Utara dan Wallacea pun masih sangat miskin dengan sebagian informasi diversitas sponge wilayah-wilayah ini tersebar dalam literaturliteratur ilmiah yang sudah usang dan terfragmentasi. Studi ini bertujuan untuk meningkatkan pengetahuan taksonomi dasar sponge di Sulawesi Utara khusunya di perairan Tahuna Kepulauan Sangihe sekaligus memberikan gambaran umum tentang distribusi dan potensi farmakologis dari sponges yang umum ditemukan di perairan Tahuna. Menggunakan metode acid digestion dan kombinasi mikroskop cahaya dan Corel Draw, kami mengidentifikasi tujuh spesies umum di terumbu karang Tahuna yaitu Agelas nakamurai, Clathria reindwardtii, Ircinia strobilina, Melophus sarasinorum, Speciospohongia vagabunda dan Xestospongia testudinaria. Selain menyentil tentang molekul-molekul bioaktif, tulisan ini juga secara singkat membahas tentang penyebaran ketujuh jenis sponge itu terutama di kawasan Asia Tenggara, selatan Jepang dan Australia untuk memperlihatkan sebaran sekaligus potensi kandungan bioaktif dan biomaterial dari sumberdaya laut amat berharga tetapi terabaikan dalam berbagai program monitoring dan konservasi terumbu karang di Indonesia ini. Sementara $M$. sarasinorum, S. vagabunda $C$. reinwardti, dan $X$. testudinaria terlihat memiliki distribusi sangat luas di wilayah Indo Pasifik, Agelas nakamurai dan I. strobilina sejauh ini baru dilaporkan di perairan Okinawa, Asia Tenggara dan Wallacea meskipun spesies serupa dari kedua genus itu terdistribusi hampir di seluruh Australia. Artikel ini mewakili laporan pertama tentang diversitas, kandungan molekul dan sebaran geografis sponge umum dari perairan Kabupaten Sangihe.
\end{abstract}

Kata kunci: Senyawa bioaktif, biomaterial, agelasines A-F, agelas nakamurai

\begin{abstract}
Sponges have attracted considerable attention not only because of their bioecological but also due to cosmetical and medical potentials of bioactive compounds and biomaterials from sponges. Unfortunately, the basic knowledge of this impressive marine invertebrate, even in rich biodiversity region such as North Sulawesi, remains poorly known with such information scattered in old and fragmented literatures. This research aimed to increase the basic taxonomic knowledge and medical potential of seven sponges in Tahuna's coral reefs Sangihe Islands as an step to encourage monitoring and concervation of this key species in coral reef in Sangihe Islands. Using acid digestion method and combination of light microscope and Corel Draw, we identified seven common species in Tahuna's coral reefs namely reinwardti, Ircinia strobilina, Melophus sarasinorum, Speciospongia vagabunda and Xestospongia testudinaria. In addition to providing a quick review on the distribution of these species especially in South East Asia, southern Japan and Australia, the authors also touched on bioactive compounds produced by these animal isolated by one of the authors either from Sangihe Island's sponges or sponges from other locations to give an overview of the bioactive potential and geographical distributions of the impressive but ignored marine resource in coral reefs' monitoring and conservation programs in Indonesia. While sepecies such as M. sarasinorum, S. vagabunda $C$. reinwardti, and $X$. testudinaria seem to well distributed in Indopasific, A. nakamurai and I. strobilina are distributed only in south Japan and Wallacea regions although the sibling species of the two sponges have been well reported throughout Australia. This article represents the first report on biodiversity, distribution and bioactive molecules of sponges from Sangihe Islands.
\end{abstract}

Keyword: Senyawa bioaktif, biomaterial, agelasines $A-F$, agelas nakamurai 


\section{PENDAHULUAN}

Monitoring keanekaragaman spesies kunci terumbu karang seperti sponge amat bergantung pada pengetahuan dasar tentang jenis-jenis sponge (Bell \& Smith 2004). Meskipun sponge termasuk salah satu spesies kunci pada ekosistim terumbu karang karena kelimpahan, dominasi dan keluasan interaksinya (Cerrano et al. 2006, Wulff 2012; Bell 2008) serta peranannya dalam memfungsikan berbagai ekosistem di laut (de Goeij et al. 2013), pengetahuan dasar tentang sponge, bahkan di wilayah kaya keragaman hayati seperti Sulawesi Utara pun, masih sangat minim (Tomascik et al. 1997; Calcinai et al., 2017). Miskinnya informasi tentang sponge di wilayah ini telah turut menyebabkan terabaikannya sponge dalam berbagai program monitoring, survei dan konservasi terutama akibat keterbatasan pengetahuan tentang taksonomi sponge (Bell and Smith 2004, Bell 2008) padahal statusnya sebagai spesies kunci di terumbu karang.

Sejumlah penelitian tentang sponge Indonesia memang telah dipublikasikan pada laporan-laporan tua seperti pada ekspedisi Snellius II dan Siboga atau pada laporan terkini seperti pada revisi genus (Sim-Smith \& Kelly, 2011; Becking, 2013), deskripsi spesies (Calcinai et al., 2013; Muricy 2011) serta ekologi, distribusi dan simbiosis sponge (Calcinai et al., 2004; Cerrano et al. 2006; de Voogd dan Cleary 2008; de Voogd et al. 2009; Powell et al., 2014; Rossi et al. 2015). Meskipun begitu, studi invertebrata laut di wilayah Sulawesi Utara terutama perairan Nusa Utara masih sangat jauh dari optimal (de Vogd \& van Soest, 2002; Calcinai et al., 2017), bukti mendesaknya upaya identifikasi sponge dari perairan Tahuna Kabupaten Sangihe.

Artikel ini mendeskripsikan tujuh sponge yang umum ditemukan pada 4 terumbu karang di Tahuna (Enepahembang, Batulewehe, Towo'e'dan Kolongan) yang dikoleksi selama bulan Juli dan Agustus 2020. Tulisan ini memberikan deksripsi morfologi seperti bentuk, warna, tekstur beserta gambar bawah air, ukuran panjang dan lebar spikula dari ketujuh sponge itu selain distribusinya di kawasan Asia Tenggara, selatan Jepang dan Australia serta kandungan bahan aktif pada ketujuh jenis sponge ini. Penelitian ini bertujuan meningkatkan pengetahuan tentang diversitas, kandungan bioaktif dan distribusi sponge dari terumbu-terumbu karang di perairan Tahuna Kabupaten Sangihe sebagai sebuah upaya awal untuk mendorong kegiatan monitoring dan konservasi sumberdaya laut penting namun terabaikan seperti sponge di Kabupaten Kepulauan Sangihe.

\section{METODE PENELITIAN}

\section{Sampling}

Sponge diambil dari perairan Enepahembang, Batulewehe, Towo dan Kolongan pada bulan Juli dan Agustus 2020. Sponge diambil dari terumbu karang di Kolongan, Batulewehe, Towo dan Enepahembang pada kedalaman 3-12 $\mathrm{m}$. Setelah pengembilan data morfologi (bentuk pertumbuhan, warna, tekstur) dan gambar bawah air, sampel-sampel sponge itu dimasukan ke dalam kantung plastik secara terpisah, ditampung dalam cool box, dibawa ke laboratorium Jurusan Perikanan dan Kebaharian Politeknik Negeri Nusa Utara dan disimpan dalam freezer $\left(-18{ }^{\circ} \mathrm{C}\right)$ sampai semua sampel itu dianalisa struktur dan diukur spikulanya.

\section{Pemurnian Spikula.}

Fragmen-fragmen akan diambil secara terpisah dari tiap sponge, dikeringkan dalam oven pada suhu $110{ }^{\circ} \mathrm{C}$ selama 15 menit jam sebelum spikulanya dimurnikan dengan acid digestion method (Hooper, 2002) dan diukur menggunakan kombinasi mikroskop cahaya dan Corel Draw (Rianti et al., 2020a, Balansa \& Rieuwpassa 2020). 


\section{HASIL DAN PEMBAHASAN}

Sebagai kelas sponge paling umum (menyusun kira-kira $80 \%$ total sponge di dunia), demospongiae memiliki kerangka struktur silika dalam bentuk tetrakson (bercabang empat) atau mono-axon atau bercabang tunggal (Ackers \& Moss, 2007). Pengujian dan pengukuran spikula memperlihatkan sejumlah tipe spikula megasklera atau berukuran $>60$ $\mu \mathrm{m}$ sebagai kunci identifikasi ketujuh sponge umum di perairan Tahuna termasuk oxea, acanthylostyle, tylostile dan subtylostyle. Berdasarkan analisis ini dan perbandingan dengan struktur morfologi termasuk spikula ketujuh jenis itu diidentifikasi sebagai Agelas. nakamurai, Melopus sarasiorum, Speciospongia vagabunda, Clathria reindwardti, Ircinia strobilina dan Aaptos suberitoides.

\section{Agelas nakamurai (Hoshino 1985)}

Dilaporkan pertama kali oleh Hoshino pada tahun 1985 dari salah satu sponge pulau Samami Okinawa, Agelas nakamurai ini masif, berwarna oranye hingga merah bata, dan memiliki spikula acanthostyle berukuran 210x10-15 $\mu \mathrm{m}$ (Gambar 1A dan 1B). Bertepatan saat ini kami sedang mengembangkan teknik pengukuran spikula baru (Balansa dan Reiuwpassa, 2020), kami juga memurnikan dan mengukur spikula dari sponge EP-15 yang awalnya diidentifikasi sebagai Agelas sp. melalui analisa DNA barcoding (Balansa et al., 2020). Ternyata, EP-15 juga mengandung spikula acanthostyle salah satu ujung runcing dilengkapi dengan 18-23 tonjolan berukuran 108.78-111.87x6.71$7.80 \mu \mathrm{m}$, spikula tipikal dari A. nakamurai (Hoshino 1985 ; Eder et al., 1999; Sarat et al., 2016; Rianti et al. 2020). Oleh karena itu, spesimen Agelas sp. dari perairan Enepahembang ditetapkan menjadi Agelas nakamurai. Identifikasi jenis ini dipertegas secara kimia oleh isolasi sejumlah senyawa yang awalnya juga ditemukan pada $A$. nakamurai yaitu agelasines A dan D dari EP-15 (Balansa et al., 2020) dan agelasines
A-F serta agelasidine D dari tiga sponge A. nakamurai perairan Tahuna lainnya (Rianti et al., 2020b) (Gambar 2C). Agelasine A-F dan agelasidine A telah berulangkali dilaporkan sebagai antikanker dan antiinfeksi dengan agelasine B mampu menginduksi apoptosis pada sel kanker payudara secara in vitro (Pimentel et al., 2013). Sejauh ini, A. nakamurai telah dilaporkan dari perairan Okinawa, Papua New Guinea dan wilayah Wallacea yakni Ambon (Eder et al., 1999), Spermonde (Sapar et al., 2014) dan Kepulauan Sangihe (Balansa et al., 2020; Ryanti et al., 2020b). Hasil cukup mengejutkan muncul saat pencarian pada basis data online Atlas of Living Australia yang memperlihatkan belum ada catatan spesies ini di Australia sampai sebagian besar Indo Pasifik meskipun spesies sangat mirip seperti Agelas mochiatii (Hoshino 1985) justru telah dilaporkan tersebar di sebagian besar Australia, wilayah Pasifik, Malaysia hingga Palau (Gambar 1C).
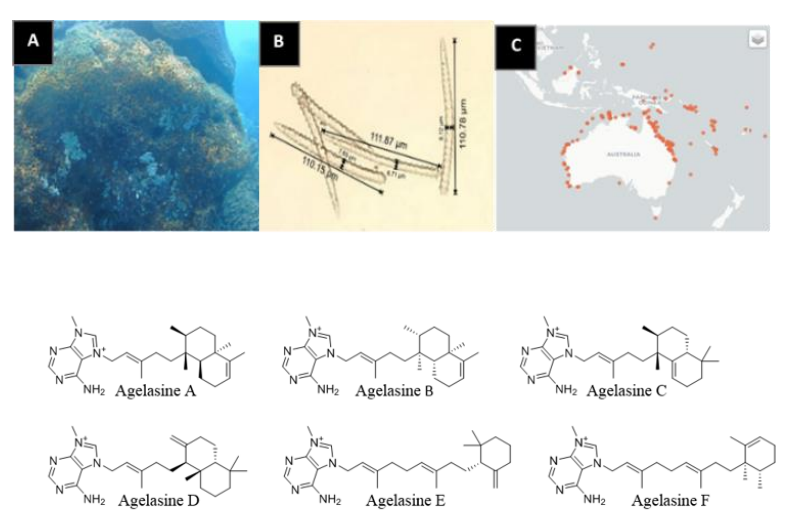

Gambar 1. A. nakamurai EP-15 (A), spikula acanthostyle dari EP-15 (B), sebaran A. mochiatti di Indo Pasifik dan Asia Tenggara dan molekul Agelasine A-F.

\section{Speciospongia vagabunda (Ridley 1884)}

Spesies sponge ini memiliki fistula (semacam cerobong asap) berbentuk silindris atau subsilindris dengan bentuk menutup atau terbuka penuh, menempel di dasar perairan dan member substrat dengan tubuh bagian bawah sponge ini biasanya terbenam pada substrat dan memiliki permukaan tubuh licin, tidak rata dan rapuh. S. vagabunda dilaporkan berwarna coklat, hijau zaitun atau jingga saat hidup dan memiliki 
spikula megasklera tylostyles (Atlas of Living Australia, 2020). Karakterisik-karakterisik morfologi ini sesuai dengan karakteristik spesimen dari perairan Enepahambang (Gambar 3A) yang memiliki bentuk fistula silindris kebanyakan terbuka, permukaan tubuh licin, agak tidak merata dan rapuh. Selain itu, spesimen sponge dari Enepahembang juga memiliki spikula tylostyle berukuran panjang 265.16 hingga $281.33 \mu \mathrm{m}$. Meskipun ukuran spikula dari spesimen Enepahembang ini relatif lebih kecil (Gambar 3B), kemungkinan akibat perbedaan lingkungan perairan, ukuran itu masih berada pada kategori megasklera (>60 mm), karenanya mendukung penetapan spesimen Enepahembang sebagai Speciospongia vagabunda. Spesimen ini telah dilaporkan memiliki distribusi sangat luas dari New Caledonia hingga Pilipina, Sri Lanka, Mauritius (Beepat et al., 2013), laut Jawa Indonesia (Hadi et al., 2018) sampai Asia Tenggara dan wilayah Indo-Pasific (Gambar 2C).

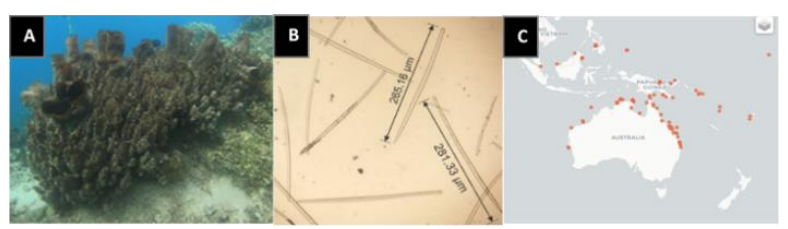

Gambar 2. Speciospongia vagabunda (A), spikula tylostyle (B), distribusi di Indo Pasifik (C)

Clathria reinwardti (Vosmaer, 1880).

Menurut Atlas of Living Australia, $C$. reinwardti memiliki bentuk pertumbuhan menyerupai pohon atau arborescent, memperlihatkan percabangan silindris atau bentuk silindris padat dan membentuk sejumlah titik pelekatan pada susbtrat. Basis data online itu juga menjelaskan bahwa percabangan dan tangkai pada substrat dengan luasan dasar sempit biasanya berhubungan dengan pangkal batang membentuk struktur kompleks saling terpilin kebanyakan dengan cabang tunggal. Spesies ini juga dilaporkan memiliki warna yang relatif stabil dari pigmentasi sangat terang mulai dari oranye hingga oranye kecoklatan, oranye-merah-coklat hingga abuabu putih dalam keadaan hidup dan orange coklat hingga abu-abut putih jika direndam dalam alkohol. $C$. reinwardti dikenal memiliki spikula tipe style dengan salah satu ujung sangat tajam dan ujung lainnya tumpul. Deskripsi morfologi ini sejalan dengan karakteristik spesimen dari perairan Batulewehe (Figure 3A and 3B). Itulah sebabnya, sponge ini ditetapkan sebagai $C$. reinwardti atau dikenal juga dengan nama sponge tali coklat. Jenis sponge ini telah dilaporkan sebagai penyusun utama perairan dangkal wilayah Mikronesia, Australia bagian utara, Torrest Straits, Papua New Guinea dan Kepulauan Solomon (Figure 3C), Asia Tenggara dan India. Manurut Kelly \& Bell (2016) kelimpahan spesis ini berhubungan erat dengan bentuk tubuhnya berupa fragmen yang mudah melekat kembali pada substrat. C. Reinwardti adalah sumber berbagai molekul seperti amida mengandung bromin, terpen, alkaloid dan berbagai molekul bioaktif lain selain memperlihatkan kemampuan menyerap logam berat (Melawaty et al., 2014).

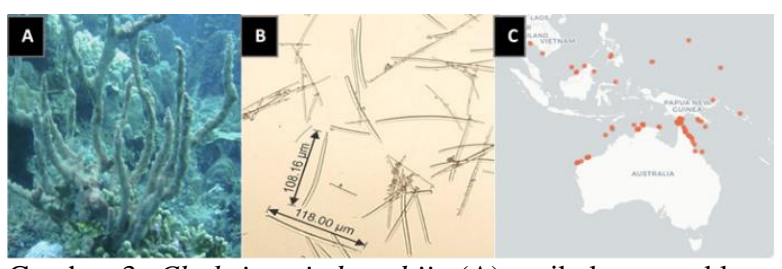

Gambar 3. Clathria reindwardtii (A), spikula megasklerea style (B) distribusinya di Asia Tenggara dan Indo Pasifik (C)

\section{Xestospongia testudinaria (Lamark, 1815)}

Sponge berbentuk drum ini keras dan tidak bisa ditekan, memiliki lubang besar di bagian tengah dan berukuran sangat besar, bisa mencapai lebih dari 1 m. Sementara bagian luar bisa berwarna jingga atau merah coklat, bagian dalamnya berwarna krim. $X$. testudinaria dilaporkan memiliki spikula tipe oxea (Hadi et al., 2018) dengan ujung bulat atau sedikit runcing berukuran 250-350x5-20 $\mu \mathrm{m}$. Deskipsideskripsi ini sangat konsisten dengan karakteristik dari spesimen sponge Batulewehe (Gambar 5A dan 5B) yang memungkinkan penetapan spesimen perairan Batulewehe sebagai Xestospongia testudinaria. Sponge ini juga diketahui memiliki distribusi sangat luas seperti perairan Tanzania (Setiawan et al., 2016), 
Thailand, Taiwan, Australia khususnya di The Great Barrier Reef (Gambar 4 C), perairan ProbolinggoSitubondo (Hadi et al. 2018), Guam and Mikronesia (Hooper and Van Soest, 2002). Ukurannya yang besar dan bentuknya yang menarik membuat sponge drum ini menjadi daya tarik wisata di seluruh wilayah IndoPasifik (Kelly \& Bell, 2016). Pada pengujian antimikroba, esktrak kasar dari $X$. testudinaria aktif terhadap bakteri Gram positif Staphylococcus aures pemurnian ekstrak itu menghasilkan beberapa senyawa dari kelompok asetilenik terbrominasi seperti xestospongic acid (Gambar 4) (data belum dipublikasikan). Salah aktivitas biologis menarik dari senyawa kelompok asitilenik terbrominasi adalah antiobesitas (Liang et al., 2014). Selain itu, tipe spikula dari X. testudinaria (oxea) sangat mirip dengan tipe spikula kecualri ukurannya dari sponge Haliclona sp. yang telah dilaporkan oleh Zhang et al. 2017; Zhang et al., 2019 dan Liang et al., 2020) sebagai spikula untuk skin drug delivery system yang penting untuk membantu pengobatan transdermal atau melalui kulit.

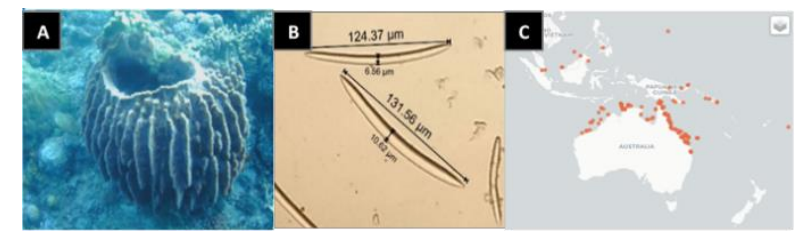

Gambar 4. Xestospongia testudinaria (A), spikula oxea megasklera (B), distribusinya di Indo Pasifik (C).

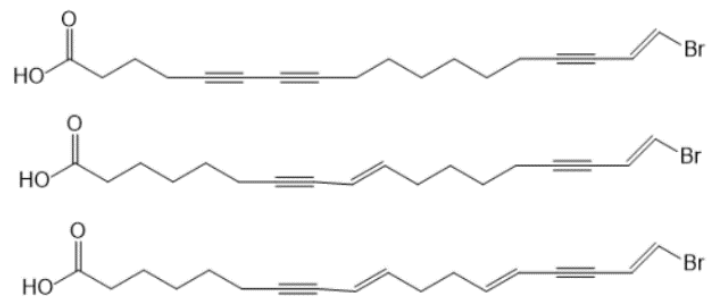

Xestospongic acids

Melophus sarasinorum Thiele (1899)
Sponge masif berbentuk bulat telur atau oval atau seperti nenas dengan warna coklat muda atau coklat gelap dan biasanya memiliki "semacam kaki" khususnya saat berukuran kecil sehingga terlihat seperti pesawat ruang angkasa alien. Tubuh sponge ini keras tapi bisa ditekan (compressible) dengan tipe spikula oxea megaskleres dengan beberapa bentuk berukuran besar dengan ujung runcing. Sponge perairan Enepahembang memperlihatkan karakteristik morfologi yang sama persis dengan Melophus sarasinorum sehingga ditetapkan sebagai $M$. sarasinorum (Gambar 5A dan 5B). Sejumlah molekul steroid sarasinoid telah dilaporkan sebagai antikanker dari M. sarasinorum. Seperti halnya $C$. reinwardti, $M$. sarsinorum juga dilaporkan memiliki kemampuan menyerap logam berat sehingga berpotensi juga untuk mengatasi masalah pencemaran ligkungan oleh logam berat. Kesamaan tipe spikula (oxea) tetapi dengan ukuran lebih besar daripada spikula Halicola yang telah dipatenkan untuk drug dilevery system memperlihatkan potensi spikula M. sarasinorum sebagai biomaterial untuk skin drug delivery system. Jenis sponge ini mewakili komunitas bentik paling umum ditemukan di Guam dan Mikronesia (Hooper and Van Soest, 2002), Asia Tenggara, Okinawa dan Australia bagian utara.

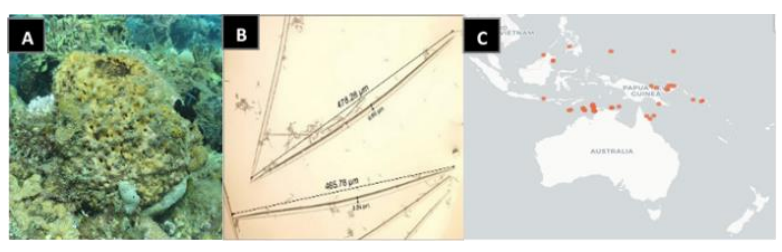

Gambar 5. Melophus sarasinorum (A) spikula oxea megasklera (B), distribusi di Indo Pasifik (C).

Ircinia strobilina (Lamarck, 1816)

Sponge berbentuk bola berwarna abu-abu, coklat maroon sampai hitam ini biasanya memiliki bagian tengah berlubang besar dengan tinggi dan diameter mencapai $\sim 26 \mathrm{~cm}$ and $\sim 22 \mathrm{~cm}$. Spesimen ini 
tidak mengandung spikula dan sangat susah disobek mengandung kolagen dan serabut filamen tersusun dari serat-serat organik (Hardoim \& Costa 2014). Spesimen Towo'e memperlihatkan karakteristik morfologi serupa termasuk ketiadaan spikula dari sponge ini sehingga spesimen ini juga diidentifiksai sebagai I. strobilina. Meskipun hingga sekarang tidak ada catatan mengenai keberadaan spesies ini di Australia, sebagian besar anggota dari genus ini terutama Ircinia Nardo justru dilaporkan teresebar luas di seluruh Australia dan Indo Pasifik (Gambar 6B). Bahkan penulis korespondensi dari artikel ini berkesempatan meneliti 7 sponge Australia dari genus Ircinidae. Penelitian-penelitian itu menghasilkan senyawa-senyawa terpene tetronik acid dan derivatnya termasuk molekul-molekul seperti ircinialactam (Balansa et al., 2010) dan ircinianin (Balansa et al. 2013) yang merupakan molekul penanda dari sponge pada genus ini. Molekul-molekul ini memperlihatkan aktivitas modulasi terhadap reseptor glisin yaitu reseptor target untuk pengobatan rasa nyeri dan epilepsi (Balansa et al., 2010; Balansa et al., 2013).

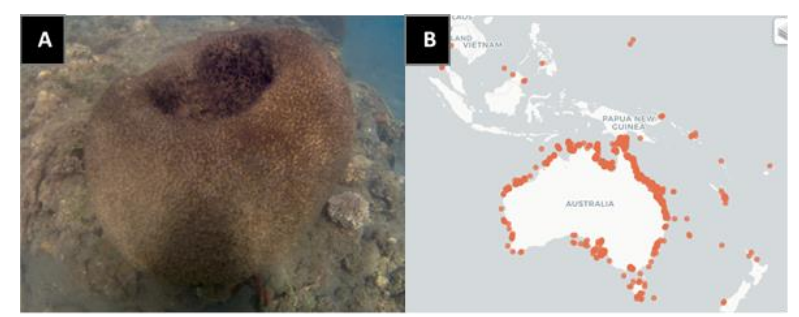

Gambar 6. Ircinia strobilina (A) dan distribusi genus Ircinia (B).

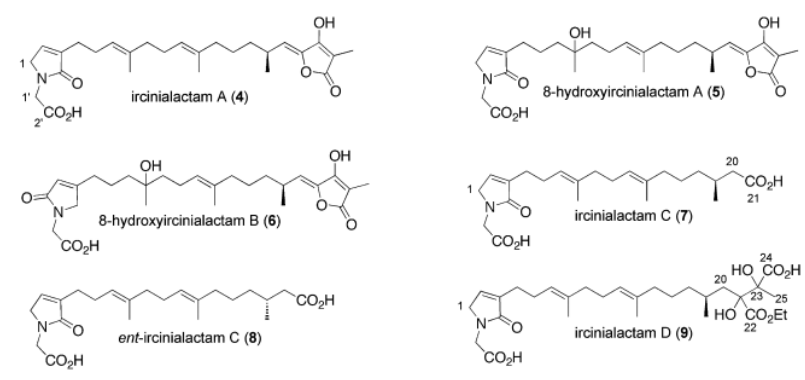

Aaptos suberitoides (Schmidt, 1864)

$\begin{array}{rccc}\text { Menurut } & \text { Calcinai } & \text { et al. } & \text { (2017) yang } \\ \text { mengidentifikasi } & \text { sejumlah sponge dari perairan }\end{array}$ Sulawesi Utara, Aaptos suberitoides tergolong sponge dengan bentuk supspherical (agak bulat) dengan warna eskterior bervariasi dari kuning ke coklat muda sampai oranye tergantung tingkat keterdedahan terhadap cahaya matahari tetapi warna interior selalu kuning. Spesies ini dilaporkan memilki spikula strongyles. Spesimen dari Batulewehe memperihatkan bentuk agak bulat dengan warna eksterior gelap cenderung hitam tetapi interior berwarna kuning dan spikula strongyles berukuran panjang 265.-352 $\mu \mathrm{m}$. Berbagai kesamaan morfologi spesimen dari Batulewehe dan $A$. suberitoides dari Manado menunjukan bahwa spesimen dari Batulewehe adalah A. suberitoides. Jenis sponge ini telah dilaporkan dari wilayah Wallacea termasuk Ambon (Pham et al., 2013), Manado (Calcinai et al. 2017) dan Okinawa meskipun hanya anggota genus Agelas lainnya seperti Aaptos aaptos yang telah dilaporkan dari Australia khususnya di the Great Barrier Reef dan sebagian wilayah Indo Pasifik (Gambar 7C).

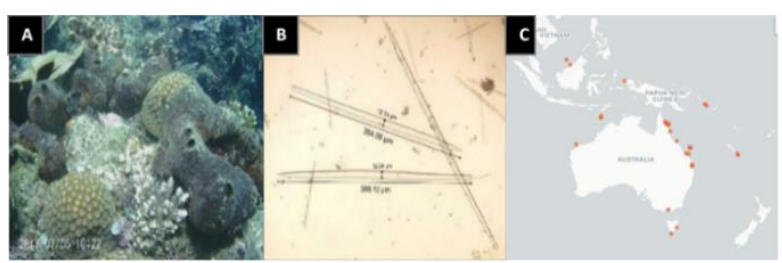

Gambar 7. Aaptos suberitoides (A), spikula strangles (B) dan distribusi genus Aaptos di Indo Pasifik (C)

\section{KESIMPULAN}

Sponge dari perairan Sangihe belum terekplorasi dengan baik dan mewakili objek yang sangat baik untuk kajian-kajian taksonomi, ekologi, pencarian berbagai bahan aktif dan biomaterial dengan beragam potensi kosmetik maupun medis yang relatif belum terungkap. Teknik permunian spikula dan pengukurannya yang relatif sederhana membuka peluang upaya untuk mendapatkan informasi taksonomi dasar yang sangat krusial untuk identifikasi spesies yang pada gilirannya berperan penting untuk monitoring dan perlindungan sumberdaya laut, apalagi dua spesies memperlihatkan potensi bioakumulator logam berat yang berpotensi mengatasi masalah 
pencemaran logam berat di lingkungan laut. Terlebih penting lagi, kandungan bahan-bahan aktif dan biomaterial sponge, terutama dari wilayah yang relatif belum terungkap seperti di Kab. Sangihe, membuka peluang penemuan-penemuan baru yang amat penting untuk kemajuan di bidang ilmu pengetahuan, kecantikan dan medis.

\section{DAFTAR RUJUKAN}

Ackers, R. G \& Moss, D. Sponges of the British Isles ("Sponge V"). A Coloud Guide and Working Document 1992 Edition, reset with modfications, 2007. Bernard E. Picton, Ulster Museum, Botanic Gardens, Belfast BT9 5AB.

Atlas of Living Australia. https://www.ala.org.au/ (diakeses awal November 2020).

Balansa, W.; Wodi, S. I. M.; Rieuwpassa, F. J.; Ijong, F. G. Agelasines B, D and antimicrobial extract of a marine sponge Agelas sp from Tahuna Bay, Sangihe Islands, Indonesia. 2020, 21, 699-706.

Balansa, W \& Rieuwpassa, F. J. Teknik Pengukuran Sponge Menggunakan Kombinasi Mikroskop Cahaya dan Corel Draw. 2019. Surat Pencatatan Ciptaan No. 0002209216. Kementerian Hukum dan Hak Asasi Manusia.

Bell, J. J \& Smith, D. Ecology of sponge assemblages (Porifera) in the Wakatobi region, southeast Sulawesi, Indonesia: richness and abundance. Journal of the Marine Biological Association of the United Kingdom, 2004, 84: 581-591. https://doi.org/10.1017/S0025315404009580h.

Bell, J.J. The Functional Roles of Marine Sponges. Estaurine, Coastal and Shelf Science. 2008, 79: 341-353. https://doi.org/10.1016/j.ecss.2008.05.002.

Beepat, S. S.; Appadoo, C.; Marie, D. E. P.; Paula, J.; Sivakumar, K. Distribution and Abudance of the Sponge Speciospongia vagabunda (Ridley, 1884) (Phylum: Porifera, Class: Demospongiae) in a Shallow Mauritiaon Lagoon. Western Indian Ocean J. Mar. Sci., 2013, 12, 15-23.

Becking, L. E. Revision of the genus Placospongia (Porifera, Demospongiae, Hadromerida, Placospongiidae) in the Indo-West Pacific. 2013, ZooKeys 298: 39-76. https://doi.org/10.3897/ zookeys.298.1913.

Calcinai, B.; Bavestrello, G.; Bertolino, M.; Pica, D.; Wagner, D.; Cerrano, C. Sponges associated with octocorals in the Indo-Pacific, with the description of four new species. Zootaxa, 2013, 3617:

$1-61$. https://doi.org/10.11646/zootaxa.3617.1.1.
Calcinai, B.; Bastari, A.; Baverstrello, G.; Bertoloni, M.; Horcajads, S. B.; Pansini, M.; Makapedua, D. M.; Cerrano, C. ZooKeeys, 2017, 680, 105150.

Cerrano C.; Calcinai, B.; Pinca, S; Bavestrello, G. Reef sponges as hosts of biodiversity: cases from North Sulawesi. In: Suzuki Y, Nakamori T, Hidaka M, Kayanne H, Casareto BE, Nadao K, Yamano H, Tsuchiya M (Eds) Xth Coral Reef Symposium, Okinawa, 2006, 208-213.

Eder, C.; Proksch, P.; Wray, V.; van Soest, R. W. M.; Ferdinandus, E.; Pattisina, L. A.; Sudarsono. New Bromopyrrole Alklaoids from the Indopasific Sponge Agelas nakamurai. J. Nat. Prod. 1999, 62, 1295-1297.

Hadi, T. A.; Hafizt, M.; Hadiyanto, Budiyanto, A.; Siringoringo, R. M. Shallow Water Sponges along the South Coast of Java, Indonesia. Biodiversitas, 2018, 19 535-543.

Hardoim, C. C. P \& Costa, R. Microbial Communities and Biocvtive Compounds in Marine Sponges of the Family Irciniidae-A Review. Mar. Drugs 2014, 12, 5089-5122.

Hoshino, Takaharo 1985. Deskripsi dua spesies baru dari genus Agelas Demospongia) dari Pulau Zamari, Ryukyus, Jepang. Prosiding Masyarakat Zoologi Jepang. 30 : 1-10.

Kelly, M \& Bell, L. J. Splendid Sponges of Palau. NIWA by TC Media Ltd. 70 pp.

Liang, L. F.; Wang, T.; He, W. F.; Cai, Y. S. Brominated polyunstaturated lipids from the Chinese sponge Xestospongia testudinari as a new class of pancreatic lipase inhibiotros. Europoen Jounal of Medicine. 2014, 79C:290297.

Liang, X. J.; Zhang, J. L.' Ou, H. L.; Chen, J.; Mitragotri, S.; Chen, M. Skin Dilivery of siRNA Using Sponge Spicules in Combination with Cationic Flexible Liposomes. Molecular Therapy Nucleic Acids, 2020, 20, 639-648.

Melawaty, L.; Noor, A.; Harlim, T.; de Voogd, N. The potential of Clathria reinwardtii as Bioaccumulator of Heavy Metal $\mathrm{Cu}$. Marina Chimica Acta, 2014, 15, 1-3.

Muricy G (2011) Diversity of Indo-Australian Plakortis (Demospongiae: Plakinidae), with description of four new species. Journal of the Marine Biological Association of the United Kingdom, $\quad$ 91(2): 303-319. https://doi.org/10.1017/S0025315410000743.

Pimentel, A.A., Felibertt, P., Sojo, F. et al. The marine sponge toxin agelasine $\mathrm{B}$ increases the intracellular $\mathrm{Ca}^{2+}$ concentration and induces apoptosis in human breast cancer cells (MCF-7). Cancer Chemother Pharmacol 69, 71-83 (2012). https://doi.org/10.1007/s00280-011-1677-x. Powell A, Smith DJ, Hepburn LH, Jones T, Berman J, Jompa J, Bell JJ (2014) Reduced Diversity and 
High Sponge Abundance on a Sedimented IndoPacific Reef System: Implications for Future Changes in Environmental Quality. PLoS ONE 9(1): e85253. https://doi. org/10.1371/journal.pone.0085253

Riyanti,; Balansa, W.; Liu, Y.; Sharma, A.; Mihajlovic, S.; Hartwig, C.; Leis, B.; Rieuwpassa, F. J, Ijong FG.; Wagele, H.; Konig, G. M.; Schaeberle, T. F. Selection of sponge-associated bacteria with high potential for the production of antibacterial compounds. Sci. Rep. (2020, Accepted).

Riyanti,; Marner, M.; Hartwig, C.; Patras, M.; Wodi, S. I. M.; Rieuwpassa F. J, Ijong, F. G.; Balansa, W.; Schaeberle, T. F. 2020, Samples by Semiautomated Prioritization of Extracts for Natural Product Research (SeaPEPR). Submitted to Marine Drugs.

Rossi G, Montori S, Cerrano C, Calcinai B (2015) The coral killing sponge Chalinula nematifera (Porifera: Haplosclerida) along the eastern coast of Sulawesi Island (Indonesia) 82: 143-148

Sapar, A.; Noor, A.; Soekamto, N. H.; Ahmad, A.; Hadi, T. H. A Preliminar Study of Bioactivity and Idnetification of Secondary Metabolites Functional Groups in Extracts of Agelas nakamurai Hoshino Sponge from Spermonde Archipelago, Indonesia. Marina Chimica Acta, 2013, 2, 5 pp.

Setiawan, E.; De Voogd, N. J.; Swierts, T.; Hooper, J. N. A.; WRoheide, G.; Erpenbeck, D. MtDNA Diversity of Indonesian barrel sponge Xestospongia testudinaria (Porifera: Haplosclerdia)-Implications from Partial Cytochrome Oxidase 1 Sequences. Journal of the Marine Biological Association of the United Kingdom, 2016, 96, 323-332.

Sim-Smith C, Kelly M (2011) Two new genera in the family Podospongiidae (Demospongiae:
Poecilosclerida) with eight new Western Pacific species. Zootaxa 2976: 32-54

Tomascik T.; Mah, A.J.; Nontji, A.; Moosa, M. K. The Ecology of the Indonesian Seas. Dalhousie University/Periplus Editions, Singapore, 1997, $1388 \mathrm{pp}$.

de Voogd NJ, Cleary DFR (2008) An analysis of sponge diversity and distribution at three taxonomic levels in the Thousand Islands/Jakarta Bay reef complex, West-Java, Indonesia. Marine ecology-an evolutionary perspective 29: 205-215. https://doi.org/10.1111/j.14390485.2008 .00238 .

de Voogd NJ, Becking LE, Cleary DFR (2009) Sponge community composition in the Derawan Islands, NE Kalimantan, Indonesia. Marine ecology progress series 396: 169-180. https:// doi.org/10.3354/meps08349.

Wulff, J.L. Ecological interactions and the distribution, abundance, and diversity of sponges. In: Becerro MA (Ed) Advances in Sponge Science: Phylogeny, Systematics, Ecology. Advances in Marine Biology, 2012, 61: 273-344. https://doi.org/10.1016/.

Zhang, X.; Ou, H.; Liu, C.; Zhang, Y.; Mitragotri, S.; Wang, D.; Chen, M. Skin Delivery of Hydrophilic Biomacromolecules Using Marine Sponge Spicules. Mol. Pharmaceutics, 2017, 9, 3188-3200.

Zhang, C.; Zhang, K.; Zhang, J.; Ou, H.; Duan, J.; Zhang, S.; Wang, D.; Mitragotri, S.; Chen, M. Skin Delivery of Hyaluronic Acid by the Combined Use of Sponge Spicules and Flexible Liposomes. Biomater. Sci., 2019, DOI: 10.1039/C8BM01555Ddst 